\title{
CONF-978834--3
}

\section{ATOM PROBE FIELD ION MICROSCOPY OF MODEL Ni-Al-Be SERAALLY}

\author{
R. C. Thomson*, K. F. Russel1** and M. K. Miller**
}

*Institute for Polymer Technology and Materials Engineering, Loughborough University, Loughborough, Leicestershire, LE11 3TU, UK.

**Metals and Ceramics Division, Oak Ridge National Laboratory, Oak Ridge, TN 37831-6376,USA.

Nickel-based superalloys used in jet engines consist of a face-centred cubic Ni matrix, $\gamma$, containing a high density of $\mathrm{Ll}_{2}$-ordered $\mathrm{Ni}_{3} \mathrm{Al}$ precipitates, $\gamma^{\prime}$. At high temperatures the strength of the alloy depends primarily on the strength of the $\gamma$ phase, which begins to decrease above approximately $750^{\circ} \mathrm{C}$, limiting the maximum operating temperature of the superalloy. The possibility of strengthening the $\gamma$ phase by solid-state precipitation within the $\gamma$ phase has been investigated in model Ni-Al superalloys containing Be. ${ }^{1}$ Beryllium, a light element, is also expected to be a potent solid solution strengthener in the $\gamma$ matrix.

Four alloys were manufactured with compositions $\mathrm{Ni}-18.8$ at. \% Al-1.6\% Be, Ni-19.0 at. \% Al-2.6\% $\mathrm{Be}, \mathrm{Ni}-17.9$ at. \% $\mathrm{Al}-5.4 \% \mathrm{Be}$ and $\mathrm{Ni}-15.9$ at. \% Al-11.9\% Be. These $\mathrm{Al}$ levels result in a volume fraction of $\gamma$ phase similar to that present in a commercial superalloy, and the Be addition places the superalloys in the $\gamma-\gamma$-NiBe region of the ternary phase diagram, Fig. 1. All alloys were homogenized at $1100^{\circ} \mathrm{C}$ for $8 \mathrm{~h}$ and then aged for various times at either 500 or $800^{\circ} \mathrm{C}$. Specimens were examined by transmission electron microscopy (TEM), and analyses were performed using Oak Ridge National Laboratory's energy-compensated atom probe with a specimen temperature of $50 \mathrm{~K}$ and a voltage pulse fraction of $20 \%$. Field ion images were recorded with neon as the imaging gas.

It is evident from Table 1 that the addition of Be produces significant hardening. In the alloy containing $1.6 \% \mathrm{Be}$, no evidence of precipitation was observed and the Be was found to remain in solid solution in the $\gamma$ and $\gamma$ phases. However, ultrafine plate-shaped precipitates were observed in the interior of the $\gamma$ phase in the higher Be alloys during the early stages of ageing, as shown in Figs. 2, 3 and 4 . In the field ion micrographs, these precipitates appeared as ultrathin brightly-imaging lines, Fig. 3. The morphology of these precipitates was analogous to that of GP zones. These precipitates were usually found to be coherent with the $\gamma$ matrix. A field ion micrograph of two precipitates intersecting a set of the (001) planes is shown in Fig. 5. In this material, atom probe analysis has revealed that the $\mathrm{Ni}$ planes in the $\gamma$ phase exhibit significantly darker contrast than the mixed $\mathrm{Ni}+\mathrm{Al}$ planes. Examination of the stacking sequence either side of the first precipitate revealed that the order of the $\mathrm{Ni}$ and mixed $\mathrm{Ni}+\mathrm{Al}$ planes is reversed and the order is restored on crossing the second precipitate. This behaviour is similar to that observed at an antiphase boundary. Atom probe analyses revealed that the composition of these precipitates is significantly enriched in Be and their concentration was found to range from $10-35$ at. $\% \mathrm{Be}^{2}$ Virtually no $\mathrm{Al}$ was observed in these ultrafine precipitates. In the later stages of ageing and with increasing Be concentration in the alloy, the density of precipitates increases and the precipitates coarsened appreciably. This is illustrated in Fig. 6 which shows a significantly thicker precipitate which features an ordered (001) pole. The composition of this precipitate was determined to be $\mathrm{Ni}-45.8 \pm 1.2 \% \mathrm{Be}-0.06 \pm 0.06 \% \mathrm{Al}$ and is therefore consistent with the $\mathrm{B} 2$-ordered $\mathrm{NiBe}$ phase, $\beta$. Therefore, $\mathrm{Be}$ additions have improved the mechanical properties of this model superalloy by a precipitation hardening mechanism within the $\gamma^{\prime}$ precipitates. This approach to improving the strength of Ni-based superalloys merits further investigation. ${ }^{3}$

1. R.C. Thomson, K.F. Russell and M.K. Miller, J. de Phys. IV, 6-C5 (1996) 259.

2. Miller M.K. and Thomson R.C., J . de Phys. IV, 6-C5 (1996) 277.

3. This research was sponsored by the Division of Materials Sciences, U. S. Department of Energy, under contract DE-AC05-96OR22464 with Lockheed Martin Energy Research Corp. and the Royal Society, U.K.. This research was conducted utilizing the Shared Research Equipment (SHaRE) User Program facilities at Oak Ridge National Laboratory.

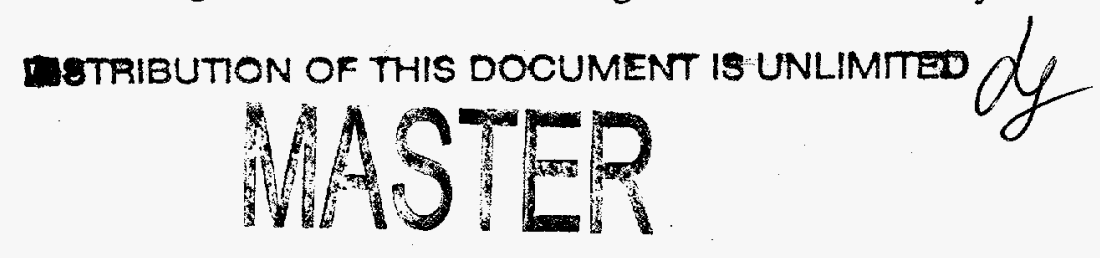

"The submitted manuscript has been authored by a contractor of the U.S. Government under contract No. Contractor of the U. S. Government under contrad Government retains a nonexclusive, royalty-tree ticense to publish or reproduce the published form of this contribution, or allow others to do so, for U.S. Government purposes." 


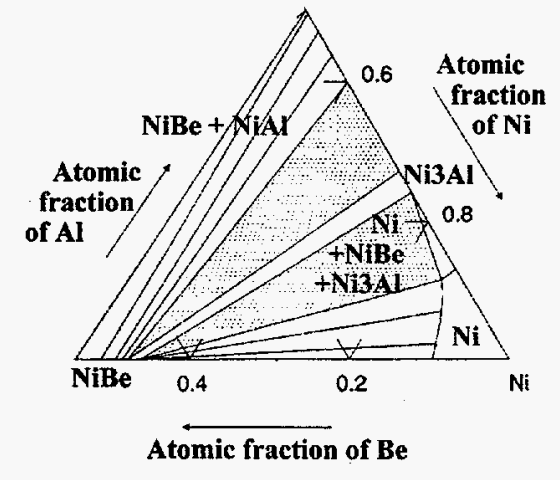

1
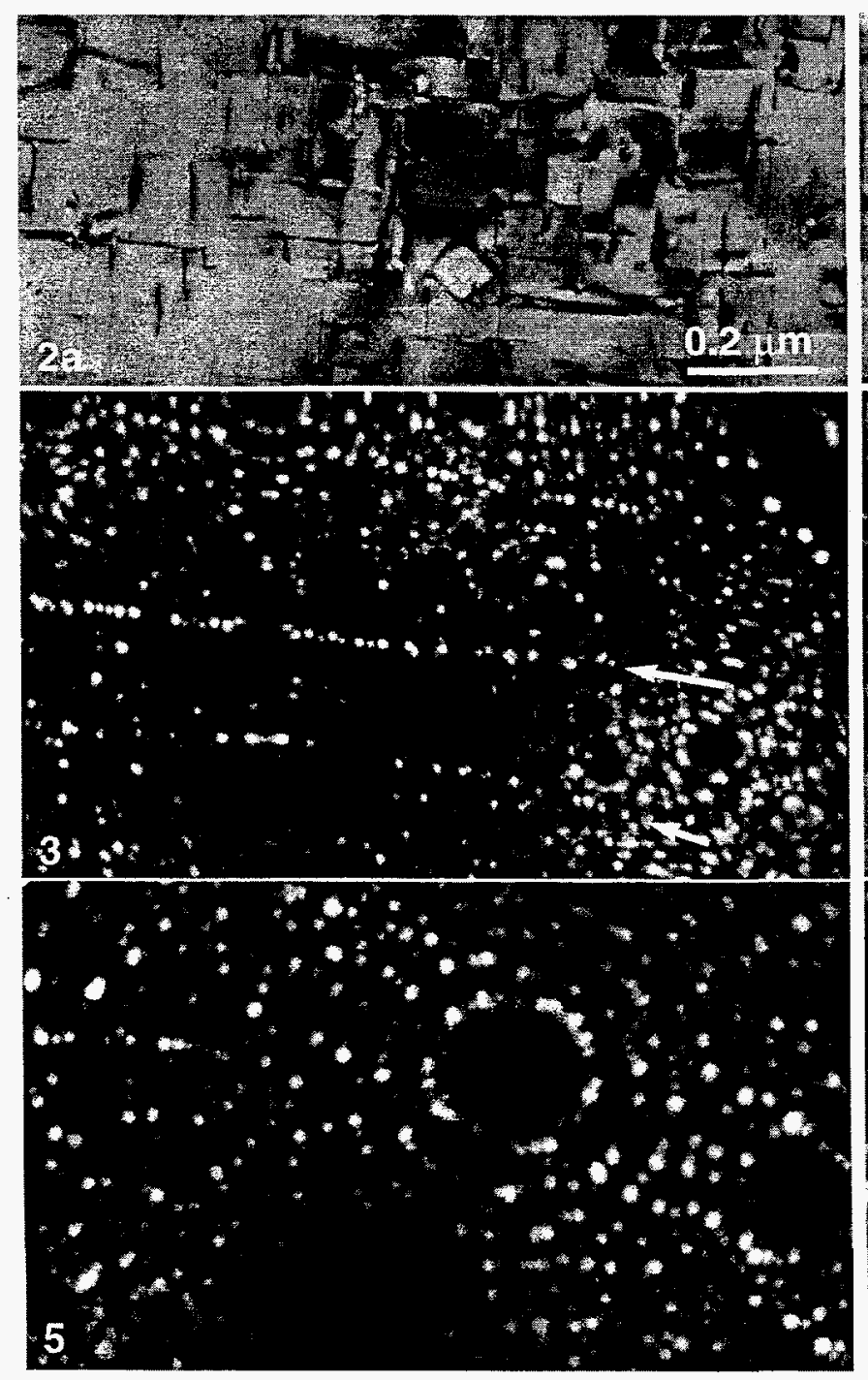

TABLE 1. Hardness data of the alloys.

\begin{tabular}{ccccc}
\hline Alloy & $1.6 \%$ & $2.6 \%$ & $5.4 \%$ & $11.9 \%$ \\
HV & $\mathrm{Be}$ & $\mathrm{Be}$ & $\mathrm{Be}$ & $\mathrm{Be}$ \\
\hline $1100^{\circ} \mathrm{C} 8 \mathrm{~h}$ & 234 & 236 & 314 & 399 \\
$+500^{\circ} \mathrm{C} 1 \mathrm{~h}$ & 215 & 254 & 327 & 415 \\
$+800^{\circ} \mathrm{C} 1 \mathrm{~h}$ & 232 & 302 & 358 & 433 \\
$+800^{\circ} \mathrm{C} 24 \mathrm{~h}$ & 229 & & 341 & \\
$+800^{\circ} \mathrm{C} 100 \mathrm{~h}$ & 229 & & 341 & \\
$+800^{\circ} \mathrm{C} 500 \mathrm{~h}$ & 238 & & 290 & \\
\hline
\end{tabular}
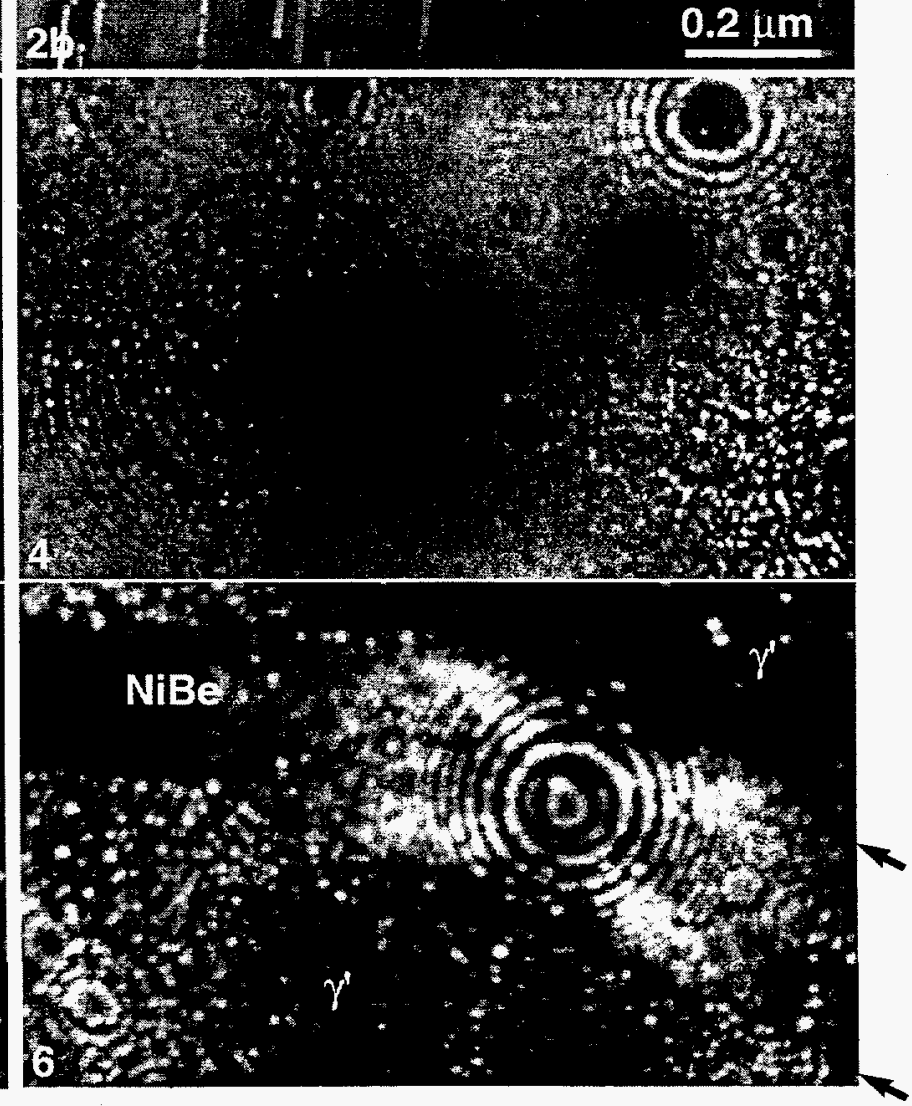

FIG. 1 - Calculated section of ternary Ni-Al-Be phase diagram.

FIG. 2 - TEM bright and dark field images showing features analogous to GP zones in the $\gamma$ phase.

FIGS. 3 and 4 - Field ion micrographs showing ultra-thin brightly imaging regions.

FIG. 5 - Field ion micrograph illustrating two adjacent precipitates, the first displacing the ordered planes in $\gamma$ phase by one layer and the second restoring the sequence.

FIG. 6 - A thicker lenticular precipitate of $\mathrm{NiBe}$ in the later stages of ageing $\left(101 \mathrm{~h}\right.$ at $\left.800^{\circ} \mathrm{C}\right)$. 


\section{DISCLAMIER}

Portions of this document may be illegible in electronic image produets. Images are produced from the best available original document. 



\section{DISCLAIMER}

This report was prepared as an account of work sponsored by an agency of the United States Government. Neither the United States Government nor any agency thereof, nor any of their employees, makes any warranty, express or implied, or assumes any legal liability or responsibility for the accuracy, completeness, or usefulness of any information, apparatus, product, or process disclosed, or represents that its use would not infringe privately owned rights. Reference herein to any specific commercial product, process, or service by trade name, trademark, manufacturer, or otherwise does not necessarily constitute or imply its endorsement, recommendation, or favoring by the United States Government or any agency thereof. The views and opinions of authors expressed herein do not necessarily state or reflect those of the United States Government or any agency thereof. 
